\title{
Amelioration Effects of Aphanizomenon Flos-aqua (AFA) on Hazardous Effects of Mixture (Sodium Benzoate, Mono Sodium glutamate and Chlorophyllin) Intake in Male Albino Rats
}

\author{
Eman G.E. Helal*1, Mohamed A. Abdelaziz ${ }^{2}$, Neama M Taha ${ }^{3}$, Nahla S.A. EL-Shenawe ${ }^{1}$ \\ ${ }^{1}$ Department of Zoology, Faculty of Science (Girls), ${ }^{2}$ Department of Physiology, Faculty of Medicine (Boys), Al- \\ Azhar University, Egypt, ${ }^{3}$ Department of Physiology, College of Medicine, Umm AL-Qura University, KSA \\ *Corresponding Author: Eman Helal, Email: emanhelal@ azhar.edu.eg, \\ Mobile: 00201001025364, orcid.org/0000-0003-0527-7028
}

\begin{abstract}
Background: Food additives are products added to the basic foodstuffs with an aim of improving its aspect, flavor, taste, color, texture, food value and conservation.

Aim of the work: This study aimed to determine the effects of AFA against the hazardous effects of sodium benzoate, chlorophyllin and monosodium glutamate. Materials and methods: This study was done on thirty male albino rats with an average body weight $120-140 \mathrm{~g}$. The animals were divided into three groups (10 rats/each) as follows: Group 1: control, Group 2: rats treated with food additives mixture (sodium benzoate, chlorophyllin, and monosodium glutamate) and Group 3: rats treated with mixture, in addition to AFA (blue green algae). Blood samples were collected, and the separated sera were used for estimation of some biochemical parameters (liver enzymes, kidney function tests, glucose, HOMA-IR, protein profile and lipid profile) and hormonal levels [testosterone, triiodothyronine (T3) and thyroxine (T4)].

Results: The study showed an increase in levels of fasting glucose, insulin, HOMA-IR, activities of AST and ALT, urea, creatinine, total cholesterol (TC), triglycerides (TG), LDL-C, VLDL, ratios of TC/HDL-C and LDL-C/HDL$\mathrm{C}$ (risk factors) in mixture group. This was accompanied by a significant decrease in protein profile (total protein, albumin and globulin), HDL-and testosterone hormone levels as compared to the control rats. On the other hand, these results turned back nearly to the normal values after receiving the AFA (blue green algae).

Conclusion: the present study clearly revealed the therapeutic capability of AFA to fight the grievous effects of food additives mixture on major physiological parameters.

Keywords: food additives, sodium benzoate (SB), Chlorophyllin(CHL), monosodium glutamate(MSG), AFA (blue green algea).
\end{abstract}

\section{INTRODUCTION}

Monosodium glutamate (MSG) is the sodium salt of glutamic acid, an amino acid that is a precursor that can lead to kidney sugar deficiency. Previous studies, which have also been confirmed in recent reports on the adverse effects of MSG, have focused on their effects on the hypothalamic-pituitary axis of the brain, leading to its neurodegenerative effects, nerve endocrine glands and induction of obesity. Recent studies have studied the metabolic and toxic effects of MSG, with a number of reports showing induction of oxidative stress in different tissues of experimental animals after the administration of chronic doses of MSG. The management of monosodium glutamate was also associated with hyperglycemia conditions based on parameters tested in the brain serum and liver of experimental animals. Increased glucose-6phosphatase activity and reduced activity of hexokinase in rat liver. Management of monosodium glutamate was also associated with increased body weight and motor activity negatively affected and altered metabolism with fat ${ }^{(\mathbf{1})}$.

Accordingly, this preliminary study investigated the ability of diets containing sodium salt of glutamic acid to alter levels of testosterone, estradiol hormones and lipid ratio as well as their ability to renounce the activity of peroxidase and RBCs ${ }^{(2)}$.

Sodium benzoate was the first preservative allowed by the FDA for use in food products. Sodium benzoate in the mitochondria of liver cells is metabolized by binding to the amino acid glycine and excreted as hippuric acid in urine. Natural excretion of hippuric acid in urine is approximately $1-2 \mathrm{~mL}$ and $400-.800 \mathrm{mg}$ of glycine is excreted as hippuric acid in the urine daily. Food consumption containing sodium benzoate increases this amount. Glycine excretion from the body indicates impaired function of the liver in metabolic processes in which glycine is essential. In addition, low glycine levels in the body can reduce creatinine levels, glutamine, urea and uric acid in the urine and increases the levels of these substances in the blood. Hydrogen and hydrophobic bonds are vital in binding sodium benzoate to the amino acid glycine and it should be noted that the limited sodium benzoate in foods is enough for this bond. on mice, sodium benzoate at a concentration of $560 \mathrm{mg} / \mathrm{kg}$ reduced the weight of the ovaries and FSH and LH hormones compared to the control group and decreased progesterone hormone at a concentration of $280 \mathrm{mg}$ compared with the control group. Another study showed that sodium benzoate at concentration of 200 
$\mathrm{mg} / \mathrm{kg}$ can decrease weight in mice and increase creatinine, urea and uric acid in the isolated serum from mice ${ }^{(3)}$. Use of sodium benzoate is not recommended in foods.

Because of more stable production than chlorophyll, chlorophyllin was widely used as a dietary supplement to accelerate healing in the treatment of kidney stones by calcium oxalate and in controlling urinary and fecal odors for aging patients. However, other studies suggest that both chlorophyll and chlorophyllin may have toxic effects on cancerous genes and intestines. Chlorophyllin can act as a positive or negative mutagenic factor, but without the dose response effect ${ }^{(4)}$.

Aphanizomenon flos-aquae (AFA) is a filamentous blue-green algal species. AFA was sold as a nutritional food supplement for about 20 years as the nutritional benefits of AFA have been appreciated by a lot of people. Aphanizomenon flos-aquae (AFA) directly metabolizes air molecular nitrogen and synthesize many low molecular weight peptide groups. These low molecular weight peptides are considered as neurotransmitters precursors that are used via various brain regions and body to initiate secretion of other substances and influence metabolic functions. The ability of the brain neurons to manufacture and utilize neurotransmitters is dependent upon food consumption and subsequently the concentration of amino acids in the bloodstream. Consumption of AFA had been found to improve many medical conditions such as Alzheimer's disease, improving the immune response, increasing fertility, reducing tumours size and occurrence, improving digestion, increasing stamina, increasing mental acuity, reducing cholesterol and protecting against radiation ${ }^{(5)}$.

BGA are nutritious natural products rich in essential amino acids, $\gamma$-linolenic acid (GLA), fibers, B vitamins, calcium, phosphorous, iron, pigments such as $\beta$-carotene, xanthophylls, and chlorophyll, and other bioactive compounds. Studies have indicated that BGA have antiviral, antitumor, antioxidant, antiinflammatory, antiallergic, antidiabetic, and antibacterial properties as well as lipid-lowering effects (6).

The aim of the current study was to determine the effects of AFA against the hazardous effects of sodium benzoate, chlorophyllin and monosodium glutamate.

\section{MATERIALS AND METHODS}

Thirty male albino rats (weighing 120-140 g) were used in this study. Animals were housed in stainless steel cages, fed on rat chew and offered water ad libitum. Animals were divided into three equal groups (10 rats/each) as follows: the first group: the control untreated group, the second group: rats were orally administered with a mixture of food additives: sodium benzoate $(5 \mathrm{mg} / \mathrm{kg}$ BW/day), Chlorophyllin $(15 \mathrm{mg} / \mathrm{kg}$ BW/day) and monosodium glutamate $(15 \mathrm{mg} / \mathrm{kg}$ BW/day) and the third group: rats were orally administrated with the previous mixture in addition to AFA (94.5 mg/kg BW/day) ${ }^{(5)}$. Body weights were recorded every week. After 30 days of treatment, animals were weighed and then decapitated after they were anesthetized with inhalation anesthesia using alcohol, chloroform, and ether in a ratio of 1:2:3 ${ }^{(7)}$. Blood samples were collected and centrifuged for 10 minutes at $5000 \mathrm{rpm}$ and sera were separated for analysis of biochemical parameters without storage or delay.

\section{Biochemical investigations}

In the present study, total proteins (TP) and albumin concentration were estimated, then serum globulin concentrations were calculated according to the formula ${ }^{(8)}$ :

Globulin $(\mathrm{g} / \mathrm{dl})=$ total proteins $(\mathrm{g} / \mathrm{dl})-$ albumin (g/dl)

Aspartate aminotransferase (AST), alanine aminotransferase (ALT) activities, creatinine, urea, fasting glucose concentrations as well as lipid profile that including total cholesterol, triglycerides LDL-C and HDL-C were also determined by using BioMerieux SA kits, France. Concentrations of testosterone and thyroid hormones (T3 and T4) were measured by using Biovendor Research and Diagnostic product reff.). Ratio of serum albumin/ globulin was determined. However, ratios of TC/HDL (risk factor 1) and LDL/HDL (risk factor 2) were also calculated after calculation of serum LDL-C (lowdensity lipoprotein cholesterol) and VLDL (very lowdensity lipoprotein cholesterol) using the Friedwald's ${ }^{(9)}$ and Norbert ${ }^{\left({ }^{10)}\right.}$ formulas, respectively as following: LDL $(\mathrm{mg} / \mathrm{dl})=$ TC $-\left\{\right.$ HDL $+[$ TG/5] $\}$. Norbert ${ }^{(10)}$ equation: VLDL $=$ TG/5.

\section{Determination of serum insulin level and HOMA- IR:}

By using an ELISA (Enzyme Linked Immunosorbent Assay) kit (U.E Type) for measurement of rat insulin with high sensitivity and rapidly using (Biovendor Research and Diagnostic product reff.) ${ }^{(11)}$.

\section{HOMA-IR:}

The approximating equation for insulin resistance, in the early model, used a fasting plasma glucose sample. Then it was calculated using insulin-glucose product divided by a constant as follows:

HOMA $-\mathrm{IR}=$ fasting glucose $\mathrm{mg} / \mathrm{dl} \mathrm{x}$ Insulin $\mu \mathrm{u} / \mathrm{L}$ 1405.

Fasting glucose in mass units $\mathrm{mg} / \mathrm{dl}$. IR is insulin resistance. Insulin is given in $\mu \mathrm{u} / \mathrm{L}^{(\mathbf{1 2})}$.

This study was conducted in accordance with ethical procedures and policies approved by Animal Care and Use Committee of Faculty of Science, Al-Azhar University, Cairo, Egypt. The study was approved by the Ethical Board of Al-Azhar University. 


\section{Statistical analysis}

The results were expressed as Mean \pm SE. Data were analyzed by one-way analysis of variance (ANOVA) and were performed using the Statistical Package for Social Sciences (SPSS) program, version 20. The Bonferroni test was used as a method to compare significance between groups. The significance level was accepted at $\mathrm{p}$-value $<0.05$.

\section{RESULTS}

Body weight: Insignificant change was noticed in the percentage of body weight change in all treated groups (Table 1).

\section{Glucose level, insulin and HOMA-IR}

There were a highly significant increase $(p<0.01)$ in glucose, insulin values and HOMA-IR ratio in the mixture group in comparison with control rats. While in the group of mixture $+\mathrm{AFA}$, there were significant increase $(\mathrm{p}<0.05)$ in glucose and HOMA-IR ratio as compared to control rats, while insulin level was insignificant change (Table 1).

Table (1): Percentage of body weight change, glucose level, insulin and HOMA-IR in control, mixture (Sodium Benzoate+ Mono Sodium glutamate + Chlorophyllin)- and (mixture+ AFA) -treated animals

\begin{tabular}{|c|c|c|c|}
\hline Groups & control & Mixture & Mixture +AFA \\
\hline $\begin{array}{l}\% \text { of body } \\
\text { weight }\end{array}$ & $\begin{array}{c}35.78 \pm \\
0.81\end{array}$ & $\begin{array}{c}37.41 \pm \\
0.7\end{array}$ & $34.27 \pm 1.57$ \\
\hline$\%$ of change & & $4 \%$ & $-4 \%$ \\
\hline Glucose (mg/dl) & $\begin{array}{c}75.41 \pm \\
2.21\end{array}$ & $\begin{array}{l}92.25 \pm \\
0.89 * *\end{array}$ & $82.39 \pm 1.12 *$ \\
\hline $\begin{array}{l}\% \text { of change } \\
\text { from control }\end{array}$ & & $22 \%$ & $9 \%$ \\
\hline Insulin $(\mu \mathrm{g} / \mathrm{dl})$ & $\begin{array}{c}4.04 \pm \\
0.37 \\
\end{array}$ & $\begin{array}{l}5.74 \pm \\
0.16^{* *}\end{array}$ & $4.83 \pm 0.28$ \\
\hline $\begin{array}{l}\text { \%of change } \\
\text { from control }\end{array}$ & & $42 \%$ & $20 \%$ \\
\hline HOM-IR & $\begin{array}{c}0.74 \pm \\
0.07\end{array}$ & $\begin{array}{l}1.30 \pm \\
0.04 * *\end{array}$ & $0.97 \pm 0.05^{*}$ \\
\hline $\begin{array}{l}\% \text { of change } \\
\text { from control }\end{array}$ & & $76 \%$ & $31 \%$ \\
\hline
\end{tabular}

Values represent mean $\pm \mathrm{SE}$ (standard error). $\left(\mathrm{P}^{*}<0.05\right.$, $\mathrm{P}^{* *}<0.01$ as compared to control group).

\section{Protein profile}

The present study showed that there was a highly significant decrease in total protein and albumin in the mixture-treated rats $(p<0.01)$ while albumin/globulin ratio recorded insignificant change as compared to control group. On the other hand, globulin recorded significant decrease $(\mathrm{p}<0.05)$ when compared to control group. While, AFA caused non-significant change in these parameters as compared to control rats (Table 2).
Table (2): Serum total protein $(\mathrm{g} / \mathrm{dl})$, albumin $(\mathrm{g} / \mathrm{dl})$, globulin and albumin globulin ratio in control, mixtureand mixtures + AFA-treated animals.

\begin{tabular}{|l|c|c|c|}
\hline \multicolumn{1}{|c|}{ Groups } & Control & Mixture & $\begin{array}{c}\text { Mixture } \\
\text { +AFA }\end{array}$ \\
\hline Total Protein (g/dl) & $\begin{array}{c}6.66 \pm \\
0.34\end{array}$ & $\begin{array}{c}4.18 \pm \\
0.09 * *\end{array}$ & $6.26 \pm 0.09$ \\
\hline $\begin{array}{l}\text { \%of change from } \\
\text { control }\end{array}$ & & $-37 \%$ & $-6 \%$ \\
\hline Albumin (g/dl) & $\begin{array}{c}3.82 \pm \\
0.25\end{array}$ & $\begin{array}{c}2.20 \pm \\
0.11 * *\end{array}$ & $3.75 \pm 0.12$ \\
\hline $\begin{array}{l}\text { \%of change from } \\
\text { control }\end{array}$ & & $-42 \%$ & $-2 \%$ \\
\hline $\begin{array}{l}\text { Globulin (g/dl) } \\
\text { \%of change from } \\
\text { control }\end{array}$ & $\begin{array}{c}2.83 \pm \\
0.25\end{array}$ & $\begin{array}{c}1.97 \pm \\
0.16^{*}\end{array}$ & $2.51 \pm 0.17$ \\
\hline $\begin{array}{l}\text { Albumin/Globulin } \\
\text { \%of change from }\end{array}$ & $1.39 \pm$ & $-30 \%$ & $-11 \%$ \\
control & 0.14 & $1.15 \pm 0.12$ & $1.52 \pm 0.15$ \\
\hline
\end{tabular}

Values represent mean \pm SE (standard error). $\left(\mathrm{P}^{*}<0.05\right.$, $\mathrm{P}^{* *}<0.01$ as compared to control group).

\section{Liver functions}

There was a highly significant increase $(\mathrm{p}<0.001)$ in ALT and AST activities in mixture-treated animals, while AFA treated group recorded a significant increase ( $\mathrm{p}<0.05)$ in ALT and AST as compared to control group (Table 3).

Table (3): ALT and AST activities in control, mixtureand mixtures + AFA-treated animals.

\begin{tabular}{|c|c|c|c|}
\hline Groups & Control & Mixture & $\begin{array}{l}\text { Mixture } \\
+ \text { AFA }\end{array}$ \\
\hline \multirow{2}{*}{ ALT (U/l) } & 22.98 & \multirow{2}{*}{$46.70 \pm 1^{* *}$} & \multirow{2}{*}{$\begin{array}{c}28.92 \pm \\
1.16^{*} \\
\end{array}$} \\
\hline & \pm 1.69 & & \\
\hline $\begin{array}{l}\text { \%of change } \\
\text { from control }\end{array}$ & & $103 \%$ & $26 \%$ \\
\hline \multirow{2}{*}{ AST (U/l) } & 51.71 & \multirow{2}{*}{$\begin{array}{c}72.3 \pm \\
0.76^{* *}\end{array}$} & \multirow{2}{*}{$\begin{array}{c}58.47 \pm \\
1.40^{*}\end{array}$} \\
\hline & \pm 1.48 & & \\
\hline $\begin{array}{l}\% \text { of change } \\
\text { from control }\end{array}$ & & $40 \%$ & $13 \%$ \\
\hline
\end{tabular}

Values represent mean \pm SE (standard error). ( $\mathrm{P}^{*}<0.05$, $\mathrm{P}^{* *}<0.01$ as compared to control group).

\section{Lipid profile}

The animals that received a mixture of food additives (group 2) had a highly significant increase in all the parameters of lipid profile $(\mathrm{p}<0.01)$, except for HDL-C level that showed a highly significant decrease $(p<0.01)$ in comparison with the control group. On the other hand, AFA-treated rats showed non-significant change in all the parameters of lipid profile, except for total cholesterol where there was a significant increase $(\mathrm{p}<0.05)$ as compared to control rats (Table 4). 
Table (4): Changes in total cholesterol (TC), triglyceride (TG), HDL-C, LDL-C, VLDL-C, LDL/HDL ratio and TC/HDL ratio in control, mixtureand mixture + AFA-treated animals.

\begin{tabular}{|c|c|c|c|}
\hline Groups & Control & Mixture & $\begin{array}{l}\text { Mixture } \\
+ \text { AFA }\end{array}$ \\
\hline $\begin{array}{l}\text { Total } \\
\text { Cholesterol } \\
(\mathrm{mg} / \mathrm{dl})\end{array}$ & $\begin{array}{c}80.00 \pm \\
1.55\end{array}$ & $\begin{array}{c}100.41 \pm \\
0.80 * *\end{array}$ & $\begin{array}{c}86.72 \pm \\
1.70^{*}\end{array}$ \\
\hline $\begin{array}{l}\% \text { of change } \\
\text { from control }\end{array}$ & & $26 \%$ & $8 \%$ \\
\hline $\begin{array}{l}\text { Triglycerides } \\
(\mathrm{mg} / \mathrm{dl})\end{array}$ & $\begin{array}{c}75.78 \pm \\
1.96\end{array}$ & $\begin{array}{c}109.72 \pm \\
1.76 * *\end{array}$ & $\begin{array}{c}78.36 \pm \\
2.36\end{array}$ \\
\hline $\begin{array}{l}\text { \%of change from } \\
\text { control }\end{array}$ & & $45 \%$ & $3 \%$ \\
\hline HDL-C (mg/dl) & $\begin{array}{c}43.75 \pm \\
1.53\end{array}$ & $\begin{array}{l}31.96 \pm \\
1.07 * *\end{array}$ & $\begin{array}{c}43.20 \pm \\
1.43\end{array}$ \\
\hline $\begin{array}{l}\text { \%of change from } \\
\text { control }\end{array}$ & & $-27 \%$ & $-1 \%$ \\
\hline LDL-C (mg/dl) & $\begin{array}{c}21.09 \pm \\
1.89\end{array}$ & $\begin{array}{c}46.51 \pm \\
1.47 * *\end{array}$ & $\begin{array}{c}27.85 \pm \\
2.46\end{array}$ \\
\hline $\begin{array}{l}\text { \%of change from } \\
\text { control }\end{array}$ & & $121 \%$ & $32 \%$ \\
\hline VLDL (mg/dl) & $\begin{array}{c}15.15 \pm \\
0.39\end{array}$ & $\begin{array}{c}21.94 \pm \\
0.35 * *\end{array}$ & $\begin{array}{c}15.67 \pm \\
0.47\end{array}$ \\
\hline $\begin{array}{l}\text { \%of change from } \\
\text { control }\end{array}$ & & $45 \%$ & $3 \%$ \\
\hline LDL/HDL & $\begin{array}{c}0.48 \pm \\
0.05 \\
\end{array}$ & $\begin{array}{r}1.46 \pm \\
0.09 * * \\
\end{array}$ & $\begin{array}{c}0.64 \pm \\
0.07 \\
\end{array}$ \\
\hline $\begin{array}{l}\% \text { of change } \\
\text { from control }\end{array}$ & & $204 \%$ & $33 \%$ \\
\hline TC/HDL & $\begin{array}{c}1.83 \pm \\
0.06 \\
\end{array}$ & $\begin{array}{l}3.15 \pm \\
0.10^{* *} \\
\end{array}$ & $\begin{array}{l}2.01 \pm \\
0.08 \\
\end{array}$ \\
\hline $\begin{array}{l}\text { \%of change from } \\
\text { control }\end{array}$ & & $72 \%$ & $10 \%$ \\
\hline
\end{tabular}

Values represent mean \pm SE (standard error). ( $\mathrm{P}^{*}<0.05$, $\mathrm{P} * *<0.01$ as compared to control group).

Kidney functions: There was an obvious increase in the levels of creatinine and urea in rats of the second group, which treated with the mixture of food additives $(p<0.01)$ while using AFA caused non-significant change in the previous levels as compared to control rats (Table 5).

Table (5): Serum creatinine and urea levels in control, mixture- and mixture + AFA-treated animals.

\begin{tabular}{|l|l|c|c|}
\hline \multicolumn{1}{|c|}{ Groups } & Control & Mixture & $\begin{array}{c}\text { Mixture } \\
\text { +AFA }\end{array}$ \\
\hline Creatinine(mg/l) & $\begin{array}{l}0.91 \pm \\
0.11\end{array}$ & $\begin{array}{c}1.30 \pm \\
0.07 *\end{array}$ & $0.94 \pm 0.01$ \\
\hline $\begin{array}{l}\text { \%of change } \\
\text { from control }\end{array}$ & & $43 \%$ & $3 \%$ \\
\hline Urea(mg/dl) & $\begin{array}{l}30.34 \pm \\
1.98\end{array}$ & $\begin{array}{c}41.45 \pm \\
1.08 * *\end{array}$ & $32.83 \pm 1.31$ \\
\hline $\begin{array}{l}\text { \%of change } \\
\text { from control }\end{array}$ & & $37 \%$ & $8 \%$ \\
\hline \multicolumn{2}{|l}{} \\
\hline
\end{tabular}

Values represent mean \pm SE (standard error). $\left(\mathrm{P}^{*}<0.05\right.$, $\mathrm{P} * *<0.01$ as compared to control group).
Hormones: T3 and T4 levels revealed insignificant change in the all treated groups concerning the control rats. Meanwhile, there was a highly significant decline $(\mathrm{p}<0.01)$ in testosterone level in the group received food additives (group 2), while there was nonsignificant change in the group that received AFA in comparison with the control animals (Table 6).

Table (6): Serum Testosterone, T3 and T4 levels in control, mixture- and mixture + AFA- treated animals.

\begin{tabular}{|l|c|c|c|}
\hline \multicolumn{1}{|c|}{ Groups } & Control & Mixture & $\begin{array}{c}\text { Mixture } \\
+ \text { AFA }\end{array}$ \\
\hline $\begin{array}{l}\text { Testosterone } \\
\text { (ng/dl) }\end{array}$ & $57.30 \pm 2.14$ & $44.06 \pm 1.85 * *$ & $53.62 \pm 1.52$ \\
\hline $\begin{array}{l}\% \text { of change } \\
\text { from control }\end{array}$ & & $-23 \%$ & $-6 \%$ \\
\hline T3 (ng/dl) & $108.22 \pm 2.27$ & $113.27 \pm 0.8$ & $110.06 \pm 1.39$ \\
\hline $\begin{array}{l}\% \text { of change } \\
\text { from control }\end{array}$ & & $5 \%$ & $2 \%$ \\
\hline T4 (ng/dl) & $4.57 \pm 0.45$ & $5.24 \pm 0.14$ & $4.98 \pm 0.20$ \\
\hline $\begin{array}{l}\% \text { of change } \\
\text { from control }\end{array}$ & & $15 \%$ & $9 \%$ \\
\hline
\end{tabular}

Values represent mean \pm SE (standard error). ( $\mathrm{P}^{*}<0.05$, $\mathrm{P}^{* *}<0.01$ as compared to control group).

\section{DISCUSSION}

Assessment of blood constituents of experimental animals as changes from the normal levels due to administration of different products consumed by humans have been continued to play valuable method in studying effects of these products on human health. The wide use of a great number of food additives has caused adverse effects on human health that require continuous evaluation ${ }^{(13)}$.

The present results revealed insignificant change in body weight gain after one month of treatment with the mixture. There might be an antagonistic effect occurred between CHL (which reduce the body weight) and MSG, (which cause obesity) to balance the both effects of the two food additives to be close to the body weight value of control rats. MSG intake that could induce an increase in energy intake, which could lead to obesity or alter the levels of carbohydrates, lipids and proteins in rats. CHL reduce the body weight because synthetic food colorants cause a significant decrease in body weight (13).

There was a highly significant increase in glucose, insulin levels and HOMA-IR in mixture group as compared to the control group. Higher HOMA-IR, serum glucose and insulin concentrations in MSGtreated rats agree with Ranjith $\boldsymbol{e t} \mathbf{a l} .{ }^{(\mathbf{1 4})}$. The increased blood glucose level following MSG administration was attributed to increased gluconeogenesis from glutamate and glutamine. Besides, the abnormal glucose tolerance could be attributed to decreased cellular insulin sensitivity even under conditions of hyperinsulinemia observed in animals treated with MSG. Under conditions of hyperinsulinemia, cells could switch to 
pathways that favor gluconeogenesis to compensate for the increased insulin release ${ }^{(15)}$.

Meanwhile, after treating with AFA, there was a reduction in glucose, insulin level and HOMA-IR concentration. Blue green algae have a high concentration of vitamins, minerals and enzymes with a complete spectrum of essential and non-essential amino acids that are all easily absorbed by the body. Due to these properties, a large number of researchers were interested in employment of blue green algae as food supplementation. It has been shown that blue green algae increases the stem cells trafficking or homing in animals through induction of a transient boosting in the population of stem cells in animal's circulatory systems. Abdelhafez et al. ${ }^{\left({ }^{(16)}\right.}$ reported that improvement in the diabetic rats treated by AFA extract might be due to stimulation of $\beta$-cells, which is in agreement with the present results.

There was a highly significant decrease in total protein, albumin, and globulin levels in mixture as compared to control rats. Liver is the primary site of the synthesis of plasma proteins. A disturbance of protein synthesis therefore occurs because of impaired hepatic functions, which lead to a decrease in their plasma concentration. The reduction of the protein concentration in the monosodium glutamate-treated rats could indicate a reduction in the synthetic function of the liver or increase rate of protein degradation ${ }^{(17)}$. Results of the present study showed that coadministration of AFA with sodium benzoate, chlorophyllin and MSG ameliorated the previous parameters. This might be due to the antioxidant activity of some AFA constituents that exhibited a hepatoprotective effect against liver damage caused by these food additives ${ }^{(\mathbf{1 8})}$.

Our study demonstrated that liver activities (AST and ALT) showed a highly significant increase in mixture that might be resulting from hepatotoxicity and liver damage, as the more severe the liver damages the higher the release of the liver enzymes. Serum levels of transaminases were used as an indicator of damage to the liver structural integrity because these enzymes are cytoplasmic in location and are released into the circulating blood only after structural damage. The sodium moiety in monosodium glutamate could easily dissociate to yield free glutamate. Thus, the possible ammonium ion overload that might occur with glutamate or monosodium glutamate intake could damage the liver, consequently releasing the transaminases; hence its observed elevation in the serum ${ }^{(17)}$. Mariyamma et al. ${ }^{(19)}$ also reported increase in plasma transaminases due to oxidative stress, which induces alteration in the membrane integrity, thus changing the membrane permeability resulting in leakage of intracellular enzymes. Helal et al. (13) reported that after oral ingestion of benzoic acid and sodium benzoate in experimental animals or humans, there was rapid absorption of the undissociated benzoic acid from the gastrointestinal tract. The substances are metabolized in the liver mainly by conjugation with glycine resulting in the formation of hippuric acid, which is rapidly excreted via the urine. Sodium benzoate caused derangement of liver function as revealed by significant elevation of serum ALT and AST as well as significant reduction of these enzymes in the liver.

AST and ALT elevation was reduced in the animals treated with AFA to a value close to the normal. This might be due to the antioxidant activity of some AFA constituents that exhibited a hepatoprotective effect against liver damage caused by these food additives ${ }^{(\mathbf{1 8})}$. This action might be due to the antioxidant activity of BGA constituents such as vitamin $\mathrm{A}$, vitamin $\mathrm{E}$ and vitamin $\mathrm{C}^{\mathbf{( 2 0 )}}$.

In the present work, treatment of rats with the mixture resulted in obvious changes in the lipid profile causing a highly significant increase in total cholesterol, triglycerides, LDL-C, VLDL-C, TC/HDL and LDL/HDL, while HDL-C showed a highly significant decrease in contrast to control rats. Several studies have shown that sodium benzoate and MSG exposure induces alterations in serum lipid profiles. The elevation in total cholesterol might be due to the mobilization of free fatty acids from the adipose tissue to the bloodstream and increase the level of acetyl CoA that leads to an increase in the synthesis of cholesterol or it might be due to peroxidation of cell membrane lipids ${ }^{(21)}$.

The effect of sodium benzoate on lipid profile and their increasing effect in cholesterol concentration in the present study might be an indication of membrane structure and function disruption, thus influencing its fluidity, permeability, activity of associated enzymes and transport system ${ }^{(22)}$.

Results of the present study, which have shown that co-administration of AFA with the mixture, ameliorated the previous parameters. Blue-green algae inhibits intestinal cholesterol absorption, decreases the hepatic lipids and leads to attenuation of plasma total cholesterol and triglycerides concentrations (21). Kushak et al. ${ }^{(23)}$ suggested that Aph. flos-aquae has a significant hypocholesterolemic properties when compared to soybean oil.

In the present study, the concentration of creatinine and urea in serum samples of the mixture group showed a highly significant increase in comparison with control rats. The elevated levels of urea and creatinine are indicator for renal dysfunction. This might be due to the oxidative stress, which caused by treatment with SB and MSG. MSG causes pathological changes in renal tissue such as necrosis and degeneration of epithelium lining renal tubules. These obtained disturbances of kidney function are in a harmony with the results of El-Ezaby et al. ${ }^{(24)}$ as they found that rats treated with MSG for 10 consecutive days showed an increased in levels of urea and 
creatinine. MSG and sodium benzoate might either interfere with creatinine metabolism leading to increased synthesis or the tissues might have compromised all or part of its functional capacity of tubular excretion ${ }^{(22)}$. However, treatment with AFA significantly improved creatinine and urea levels. This might be due to its antioxidant properties that improve renal functions via attenuating an oxidative stressmediated decline in GFR and renal hemodynamics ${ }^{(25)}$.

The previous results, showed a highly significant decrease in the mixture group in testosterone level. Food additives work to reduce androgens, which indirectly affect the axis connecting the pituitary gland. This has negative effects on social behavior and the relative weight of the sex hormoneproducing members ${ }^{(26)}$. MSG causes reduction in testosterone hormone as it obstructs the hypothalamicpituitary-testes regulatory axis that controls testosterone production by testicular Leydig cells ${ }^{(27)}$. Benzoate decreases testosterone level due to increased oxidative stress. Oxidative stress may suppress the sensitivity of the gonadotrophic cells to gonadotropinreleasing hormone. Therefore, may prevent gonadotropin secretion ${ }^{(22)}$. Meanwhile, AFA recorded a significant improvement in the value of testosterone hormone and elevated its level as compared to the mixture-treated animal. Eid et al. ${ }^{(28)}$ demonstrated that treatment of the exposed group with AFA caused improvement in testosterone level. There are no available researches concerning the radioprotective role of AFA on the mammalian testes, so we used Spirulina from the same family as references. Spirulina maxima extract (SME) intake for 4 weeks in improved the fertility of diabetic male rats where Spirulina maxima significantly increased testicular and body weights. In addition to normal seminiferous tubules, Leydig cell numbers and enhancement of metabolic parameters and testosterone levels in the streptozotocin (STZ)-treated rats ${ }^{(\mathbf{2 6}-\mathbf{2 8})}$.

The current investigations demonstrated that the daily intake of mixture group exhibited an insignificant change in thyroid hormones $\mathrm{T} 3$ and $\mathrm{T} 4$, which might be due to antagonestic effect between SB (which reduces thyroid hormones T3 and T4) and MSG (which causes increase thyroid hormones $\mathrm{T} 3$ and T4). These changes in thyroid hormones might be due to alteration in the pituitary-thyroid axis. This might play a role in children hyperactivity probably through affecting higher centers in the brain. It was documented that MSG causes endocrine disorder as a result for induced oxidative stress in experimental animals. On other hand, decrease in T3 and T4 is associated with an overall increase in oxidative stress due to treatment with sodium benzoate. Other than the decrease in thyroid function due to oxidative stress, loss of thyroidhormone-binding proteins in urine could be another cause of the decrease in serum T3 and T4 levels by sodium benzoate, which causes oxidative stress on thyroid function ${ }^{(\mathbf{1 3})}$.

\section{CONCLUSION}

It could be concluded that food additives have extreme destructive effects on most physiological parameters like liver and kidney enzymes, thyroid and testosterone hormones and lipid and protein profiles. Therefore, we should minimize their use in most foods especially for kids. In addition, we recommend the use of AFA as it achieved excellent therapeutic effects against the abnormal results that occurred to animals due to food additives administration.

\section{REFERENCES}

1. Okwudiri OO, Sylvanus AC, Peace IA (2012): Monosodium glutamate induces oxidative stress and affects glucose metabolism in the kidney of rats. International Journal of Biochemistry Research \& Review, 2 (1): 1-11

2. Ibegbulem CO, Chikezie PC, Ukoha AI et al. (2016): Effects of diet containing monosodium glutamate on organ weights, acute blood steroidal sex hormone levels, lipid profile and erythrocyte antioxidant enzymes activities of rats. Journal of Acute Disease, 5 (5): 402407.

3. Shahmohammadi M, Javadi M, Nassiri-Asl M (2016): An Overview on the Effects of Sodium Benzoate as a Preservative in Food Products. Biotechnology and Health Sciences, 3 (3): 711

4. Silva Leite V, Oliveira RJ, Nakamura Kanno TY et al. (2013): Chlorophyllin in the intra-uterine development of mice exposed or not to cyclophosphamide. Acta Scientiarum. Health Sciences, 35 (2): 201-210.

5. Abu-Amara TM, Abdelghany AH, Meselhy AE (2016): Assessment of Aphanizomenon Flos-Aquae (AFA) Food Supplement Against Cerebral Cortex Neuronal Injury Induced by Gamma Radiation. American Journal of Food Science and Nutrition Research, 3 (4): 81-89.

6. Ku CS, Yang Y, Park Y, Lee J (2013): Health benefits of blue-green algae: prevention of cardiovascular disease and nonalcoholic fatty liver disease. Journal of Medicinal Food, 16 (2): 103-111.

7. Buxton D W (1888): The use of anesthetics. The Lancet, 132 (3401): 888-889.

8. Young DS (2001): Effects of disease on Clinical Lab. Tests, 4th ed AACC. WB Saunders company, Philadelphia, Pp: 147 - 148 .

9. Friedewald WT, Levy RI, Fredrickson DS (1972): Estimation of the concentration of low-density lipoprotein cholesterol in plasma, without use of the preparative ultracentrifuge. Clin Chem., 18: 499-502.

10. Norbert WT (1995): Clinical guide to laboratory tests. 3rd ed. Saunders W. B., Company, Philadelphia. https://onlinelibrary.wiley.com/doi/abs/10.1111/j.15372995.1995.tb03571.x

11. Reeves WG (1983): Insulin antibody determination: Theoretical and practical consideration. Diabetologia, 24 (6):399-403.

12.12-Matthews DR, Hosker JP, Rudenski AS, Treacher DF et al. (1985): Homeostasis model assessment: insulin resistance and beta cell function 
from fasting plasma glucose and insulin concentration in man. Diabetologia, 28 (7): 412-419.

13. Helal EG, Abdelaziz MA, EL-Shenawe NS (2019): Adverse Effects of Two Kinds of Food Additive Mixtures (Sodium benzoate + Monosodium glutamate, Monosodium glutamate + Chlorophyllin and Sodium benzoate + Chlorophyllin) on Some Physiological Parameters in Male Albino Rats. The Egyptian Journal of Hospital Medicine, 75 (4): 2736-2744.

14. Ranjith V, Radika MK, Anuradha CV (2013): Effect of Troxerutin on Insulin Resistance Induced by PostNatal Administration of Monosodium Glutamate: A Comparative Study with Rosiglitazone. J Clin Lab Investiga Updat, 1: 36-47.

15. Tawfek N, Amin H, Abdalla A, Fargali S (2015): Adverse effects of some food additives in adult male albino rats. Current Science International, 4 (4): 525 537.

16. Abdelhafez H M, Abu-Amara T M, El-Debsi S M (2015): Evaluation of Role of Glibenclamide and Aphanizomenon flos-aquae Extract on Lymph Node and Spleen of Diabetic Rats. The Egyptian Journal of Hospital Medicine, 61:700-720

17. Okediran BS, Olurotimi AE, Rahman SA et al. (2014): Alterations in the lipid profile and liver enzymes of rats treated with monosodium glutamate. Sokoto Journal of Veterinary Sciences, 12 (3): 42-46.

18. Elmalawany A, Tarek A, Salem T (2014): Effect of blue green algae on some biochemical and hematological markers in mice. International Journal of Advanced Research, 2 (2): 568-574.

19. Mariyamma T, Sujatha KS, Sisilamma G (2009): Protective effect of Piper longum (Linn.) on monosodium glutamate induced oxidative stress in rats. Indian Journal of Experimental Biology, 47 (3): 186192.

20. Kay RA (1991): Micro algae as food and supplement. Crit Rev Food Sci Nutr., 30(6):555-73.

21.Helal EG, El-Sayed RA, Mostafa-Hedeab G et al. (2017): The Therapeutic Effects of Stem Cell Enhancer on Changes of Some Physiological Parameters in Male Albino Rats Treated With Mixture of Food Additives) Food Preservative, Food Coloring Agent, and Flavor Enhancer). Egyptian Journal of Hospital Medicine, 67 (2): 591-598.

22. Helal E G, Barayan A W, Abdelaziz M A, ELShenawe NS (2019): AdverseEffects of Two Kinds of Food Additive Mixtures (Sodium benzoate + Monosodium glutamate, Monosodium glutamate + Chlorophyllin and Sodium benzoate + Chlorophyllin) on Some Physiological Parameters in Male Albino Rats. Egyptian Journal of Hospital Medicine, 75 (4): 27362744

23. Kushak R I, Drapeau C, Van Cott EM, Winter HH (2000): Favorable effects of blue-green algae Aphanizomenon flos-aquae on rat plasma lipids. $J$ Am Nutraceutical Assoc., 2 (3): 59-65

24. El-Ezaby M M, Abd-El Hamide N H, Abd ElMaksoud M A E et al. (2018): Effect Of Some Food Additives On Lipid Profile, Kidney Function And Liver Function Of Adult Male Albino Rats. Journal of Basic and Environmental Sciences, 5:52-59.

25. Kuriakose G (2008): Evaluation of Renoprotective Effect of Aphanizomenonflos-aquae on CisplatinInduced Renal Dysfunction in Rats. Renal Failure, 30 (7): 717-725.

26.Sun Y, Hsu H, Lue Set al. (1991): Sex-Specific impairment in sexual and ingestive behaviors of monosodium glutamate-Treated rats. Physiol Behav., 50 (5): 873-880.

27. Bodnar I, Gooz P, Okamura H et al. (2001): Effect of neonatal treatment with monosodium glutamate on dopaminergic and L-dopaminergic neurons of the medial basal hypothalamus and on prolactin and $\mathrm{MSH}$ secretion of rats. Brain Research Bulletin, 55 (6): $767-$ 74.

28. Eid FA, Abdelhafez HM, Zahkouk SA et al. (2016): The radioprotective role of Aphanizomenon flos-aquae (AFA) on testis of adult male albino rats. Journal of Bioscience and Applied Research, 2 (6): 426- 439. 